\title{
MOSSES FROM THE NETHERLANDS ANTILLES
}

\author{
P. A. FLORSCHUTZ \\ (Botanical Museum and Herbarium, Utrecht)
}

(received December 1st, 1965)

The Netherlands Antilles comprise the islands Aruba, Curaçao and Bonaire of the Leeward Group, and St. Eustatius, Saba and the southern part of St. Martin (St. Maarten) of the Windward Group. The northern part of St. Martin belongs to the French territory (Département de la Guadeloupe).

Botanical investigations were started already in the 18th century, but it was not before 1909 that an enumeration of the vascular plants of part of the Netherlands Antilles appeared in print (BoLDINGH, 1909; the other part appeared in 1914). In 1913 BoLDing published a Flora of the Netherlands Antilles (in Dutch). Brother M. ARnoldo published a Flora of Curaçao, Aruba and Bonaire (in Dutch, 1954; second edition 1964). An elaborate study of the vegetation of the islands was published by StOFFERs (1956). Some of the data given below are borrowed from that paper. A new Flora is now in the course of publication (edited by STOFFERs since 1962).

In spite of all these botanical investigations it seems that nothing has been published on the bryophytes of the islands. In this paper I have listed a number of mosses collected in recent years. Of the collectors mentioned by STOFFERs (l.c.) the following persons also collected bryophytes:

W. F. R. Suringar, 1885; his collections are in the Rijksherbarium, Leiden. As already said for the Suriname collections made by Suringar (FlorschüTz, 1964), his specimens have been named by v. d. Sande Lacoste and, without being published, have been inserted under those names. In due time they will have to be selected by going through all South American mosses at Leiden. A few specimens were met with accidentally and these are listed below.

P. Wagenaar Hummelinck, 1937, 1949, 1955.

Brother M. Arnoldo, since 1945.

A. C. J. Burgers, 1948.

A. L. Stoffers, 1952-'53 and 1963.

Finally I collected a few specimens during a one-day trip to the Christoffelberg in Curaçao in 1965. Apart from those collected by Suringar, all specimens are in the Utrecht Herbarium.

The mossflora of the Leeward Group is very poor. The climate is relatively dry, the mean rainfall during a year being $359 \mathrm{~mm}$ in Aruba, $525 \mathrm{~mm}$ in Bonaire and $516 \mathrm{~mm}$ in Curaçao. It seems that no mosses have been collected in Aruba. It is by far the driest island and there are no high hilltops, the highest elevation being $188 \mathrm{~m}$. Although the rainfall in Bonaire is distinctly higher than in Aruba, only 3 mosses, Hyophila microcarpa, $H$. tortula and Gymnostomiella orcuttii, 
have been collected in this island up till now. The lack of real forest possibly prevents the establishment of more moisture-loving species in this island. From Curaçao 6 species are listed below, five of which have been collected on the highest hill (Christoffelberg, $372 \mathrm{~m}$ ) in the western part of the island with a relatively luxuriant forest vegetation. In the lower parts of this island only Hyophila microcarpa is met with occasionally.

The Windward islands Saba and St. Eustatius have by far the richest bryoflora of the Netherlands Antilles. This is mainly due to the higher elevation (St. Eustatius $600 \mathrm{~m}$ and Saba $900 \mathrm{~m}$ ) and to the higher rainfall (mean rainfall during a year 1110 and 1133 $\mathrm{mm}$ respectively for the lowlands; on top of the mountains probably more than $2000 \mathrm{~mm}$ ). According to Stoffers an elfin woodland (mossy forest) is to be found on the highest parts of these islands. St. Martin, on the contrary, is very poor in mosses. Although the rainfall is nearly as high as in Saba and St. Eustatius (1027 mm) the highest elevation is only $400 \mathrm{~m}$ and real forest is not present. Only 2 species, i.c. Stereophyllum cultelliforme and Hyophila tortula have been collected in the French part, just across the border. From Saba 17 species are mentioned and from St. Eustatius 13 species are known. Although most of the moss species mentioned below are widely distributed in the Caribbean area and beyond, it is curious that these two islands, only about $30 \mathrm{~km}$ apart, have only 3 species, i.c. Hyophila tortula, Trichostomum jamaicense and Acroporium pungens, in common. The vascular plant vegetation as described by Stoffers is indeed different, but ecological circumstances do not seem to differ to such an extent that common tropical American mosses, such as Groutiella mucronifolia, Meteoriopsis remotifolia, Neckeropsis undulata and Orthostichopsis tetragona, will not find a suitable habitat for establishment in both these islands. Probably more intensive mosscollecting in the islands will reduce these differences.

As already said above, most of the species mentioned in this paper are widely distributed over tropical America, one third of the total number even ranging from the Southern United States via the West Indies, Mexico and Central America to tropical South America. Only a few species are recorded here for the first time outside their known area. Campylopus trachyblepharon was hitherto only known from Brazil and British Guiana. A new variety of $C$. atratus Broth. (var. sabaensis) is described below. The typical variety has been collected only once on Mount Roraima in British Guiana. Although Syrrhopodon incompletus var. incompletus has a very wide distribution in tropical America, its var. luridus has thus far been found only in the Guianas. For Clasmatodon parvulus this is the first record outside the North American mainland (apart from one locality in Europe).

\section{Fissidentaceae}

Fissidens elegans Brid. (syn. $F$. guianensis Mont.) Curaģao: Arnoldo 2215A, Stoffers s.n., Florschütz 3459, Christoffelberg, on decaying 
wood. In my recent paper (FLoRschütz, 1964) I excluded this name from the Suriname flora because of the fact that the isotypes I had seen belonged to two different species. After the paper had been printed I was able to examine the holotype from the Bridel herbarium in Berlin. It consists of two plants (see fig. 1) and these plants are identical with $F$. guianensis. The latter name will have to be replaced by $F$. elegans. It is clear that the use of the name $F$. elegans for $F$. intermedius (as done in so many bryological papers) is incorrect.

Fissidens kegelianus C. M. CuraçAo: Florschütz 3458, Christoffelberg, on soil.

\section{Dicranaceae}

Campylopus atratus Broth., not Bartr. var. sabaensis Florsch. var. nov.

A varietate typica differt foliis siccitatis adpressis, dimidio brevioribus, $4 \mathrm{~mm}$ longis, minus subtubulosis. SABA: Arnoldo $3354 \mathrm{~A}$, The Mountain, top, ca. $900 \mathrm{~m}$ (type specimen, $\mathrm{U}$ ). The typical variety has been collected only on top of Mount Roraima, British Guiana. It is very easy to know by the leafcells with thick, strongly pitted walls even at extreme apex, together with the hyaline hairpoint. This new variety has shorter leaves, only about $4 \mathrm{~mm}$ long, strongly appressed to the stem when dry and less subtubulose than in the typical variety.

Campylopus trachyblepharon (C.M.) Mitt. SABA: Arnoldo 3353B, 3354D, The Mountain, top; Stoffers 3463A, The Mountain, top, $825 \mathrm{~m}$, epiphyte. This seems to be the first record outside the South American mainland.

\section{LEUCOBRYAGEAE}

Leucobryum albidum (Brid.) Lindb. ST. Eustatius: Stoffers 3681, 3698A, The Quill, top, 350-400 m; Stoffers 3956, The Quill, top, $400-480 \mathrm{~m}$, on rocks; Burgers s.n., The Quill. As already pointed out by BarTram (1949) the differences between $L$. albidum and $L$. polakowskyi (C.M.) Card. are very slight and not convincing.

Octoblepharum albidum Hedw. CuraçAo: Burgers s.n., Stoffers s.n., Florschütz 3453, Christoffelberg. St Eustatius: Arnoldo 3210A, The Quill, $500 \mathrm{~m}$.

Octoblepharum pulvinatum (Dozy et Molk.) Mitt. St. Eustatrus: Stoffers 3698B, The Quill, top, 350-400 m, epiphyte.

\section{Calymperaceae}

Calymperes donnellii Aust. St. Eustatius: Stoffers 3597, The Quill, top at side of Glass Bottle, 380-400; Arnoldo 3212, The Quill, top, $500 \mathrm{~m}$.

Calymperes richardii C.M. Curaçao: Stoffers s.n., Knip-hills, on stone wall; Florschütz 3455, Christoffelberg, on soil. SABA: Stoffers 4328 , Windwardside, on wall, $400 \mathrm{~m}$. 
P. A. FLORSGHÜTZ: Mosses from the Netherlands Antilles

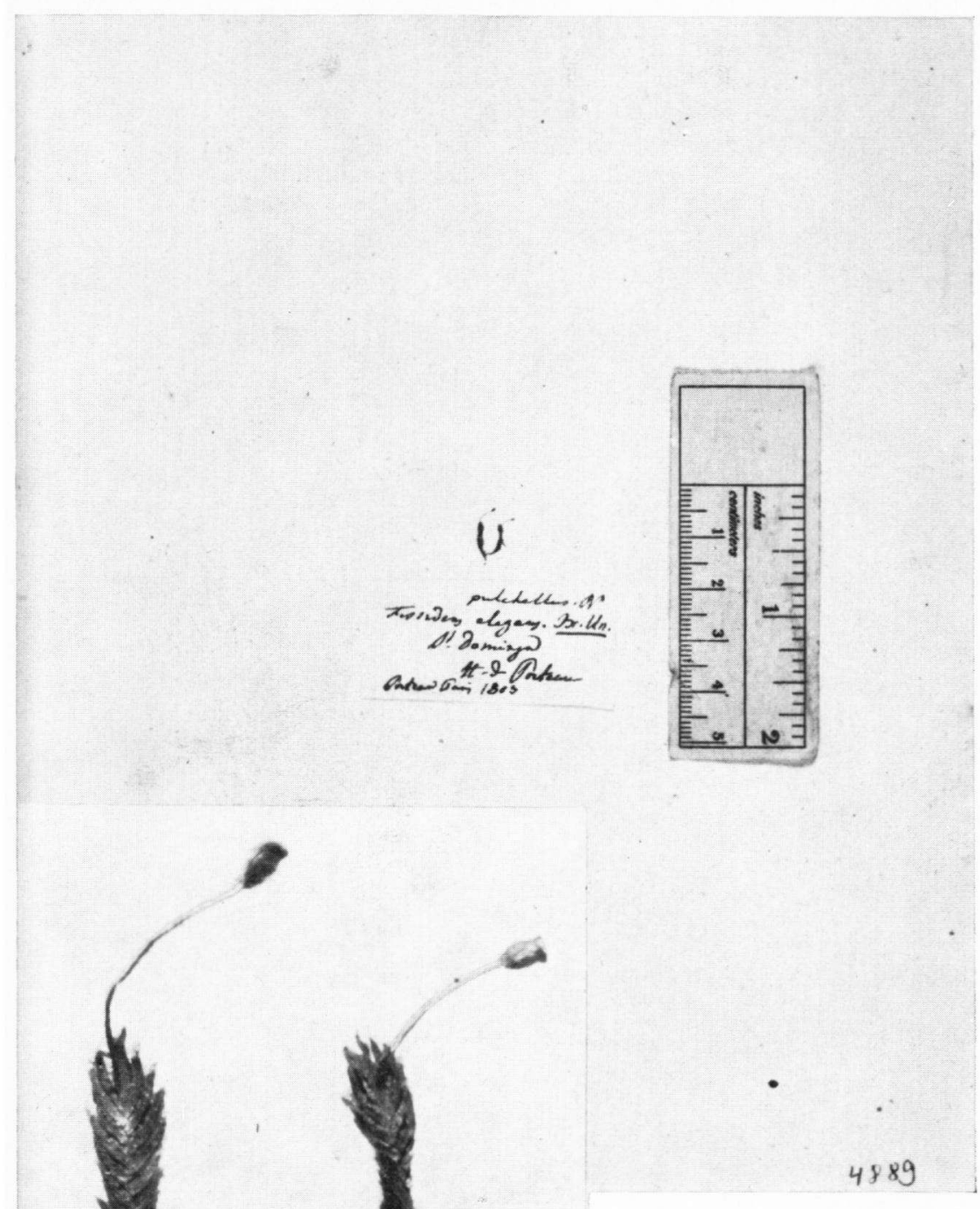

Plate I. Photograph of holotype of Fissidens elegans Brid. (Bridel herbarium, Berlin). Left below: the two plants much enlarged.

Facing p. 526 
Syrrhopodon incompletus Schwaegr. var. incompletus. ST. Eustatius: Arnoldo 3207, 3210, The Quill, $500 \mathrm{~m}$. - var. luridus (Par. et Broth.) Florsch. St. Eustatius: Stoffers 3698, The Quill, top, 350-400 m, epiphyte.

\section{Pottiaceae}

Barbula agraria Hedw. St. Eustatius: Suringar s.n., between village and The Quill.

Gymnostomiella orcuttii Bartr. BoNAIRE : Wagenaar Hummelinck 188B, Spelonk, calcareous rock, shade.

Hyophila microcarpa (Schimp.) Broth. BonaIRE: Stoffers 753, Slagbaai Plantage, Hoge weg; Stoffers 834, Angola, $50 \mathrm{~m}$; Stoffers 923, Seroe Grandi, 100-115 m; Stoffers 1046, Seroe Grandi, top, $200 \mathrm{~m}$; Stoffers s.n., Brandaris. Curaçao: Arnoldo 2213, Christoffelberg; Stoffers s.n., Ronde Klip, north escarpment, calcareous soil; Stoffers s.n., Ronde Klip, north slope, calcareous soil on top of diabase; Stoffers s.n., Jan Thiel; Stoffers s.n., Knip-hills; Florschütz 3454, Christoffelberg, on soil. SABA: Arnoldo 3276, Boobyhill, $600 \mathrm{~m}$.

Hyophila tortula (Schwaegr.) Hampe. BonaIre: Wagenaar Hummelinck 48A, Fontein hofje, calcareous rock. SABA: Arnoldo 3275, Boobyhill, $600 \mathrm{~m}$. ST. Eustatius: Suringar s.n., between village and The Quill. St. Martin: Wagenaar Hummelinck s.n., Colombier Valley, calcareous rock.

Trichostomum jamaicense (Mitt.) Jaeg. SABA: Arnoldo 3345, The Mountain. St. Eustatius: Burgers 190, The Quill, in crater.

\section{Bartramiageae}

Philonotis uncinata (Schwaegr.) Brid. var. glaucescens (Hornsch.) Florsch. Curraçao: Arnoldo 2215, Stoffers s.n., Christoffelberg.

\section{Orthotrichaceae}

Groutiella mucronifolia (Hook. et Grev.) Crum et Steere. SABA: Stoffers 4342, 4352, Santa Cruz, 500-600 m; Arnoldo 3355, The Mountain.

Macromitrium cirrosum (Hedw.) Brid. SABA: Arnoldo 3355A and s.n., The Mountain.

Macromitrium schwaneckeanum Hampe. SABA: Arnoldo 3354B, The Mountain, top.

Macromitrium scoparium Mitt. SABA: Arnoldo 3353, The Mountain, top; Stoffers 3468, The Mountain, top, $825 \mathrm{~m}$, epiphyte.

\section{Pterobryaceae}

Orthostichopsis tetragona (Hedw.) Broth. St. Eustarıus: Burgers s.n., The Quill; Stoffers 3682, 3688, The Quill, top, 350-400 m, epiphyte. Pireella pohlii (Schwaegr.) Card. St. Eustatius: Arnoldo 3208, The Quill, $500 \mathrm{~m}$. 
Meteoriaceae

Meteoriopsis remotifolia (C.M.) Broth. SABA: Arnoldo 3343, 3352, s.n., The Mountain, on tree; Stoffers 3223, The Mountain, slope under the Cliff, $680 \mathrm{~m}$; Stoffers 4630 , The Mountain, top, $800 \mathrm{~m}$. Squamidium nigricans (Hook.) Broth. SABA: Arnoldo s.n., The Mountain.

\section{NeCKeraceae}

Neckeropsis undulata (Hedw.) Reichardt. St. Eustatius: Arnoldo 3209, The Quill, $500 \mathrm{~m}$.

Porotrichum insularum Mitt. SABA: Suringar s.n., The Mountain; Stoffers 3463A, The Mountain, top, $825 \mathrm{~m}$.

\section{HoOKeriaceae}

Lepidopilum radicale Mitt. SABA: Suringar s.n., The Mountain, 600-800 m; Arnoldo 3347A and s.n., The Mountain, on tree.

\section{Fabroniaceae}

Clasmatodon parvulus (Hampe) Sull. SABA: Arnoldo 3346A, The Mountain. Apart from one locality in Europe, this seems to be the first record outside the North American mainland.

\section{Plagiotheciaceae}

Stereophyllum cultelliforme (Sull.) Mitt. St. MARTin: Wagenaar Hummelinck s.n., Golombier Valley, calcareous rock.

\section{Sematophyllaceae}

Acroporium pungens (Hedw.) Broth. SABA: Arnoldo 3342, 3346B, The Mountain. St. Eustatius: Stoffers 3963, The Quill, top, 400$480 \mathrm{~m}$.

Sematophyllum caespitosum (Hedw.) Mitt. SABA: Stoffers 4328A, Windwardside, on wall, $400 \mathrm{~m}$; Stoffers 4352, Santa Cruz, 500-600 m.

\section{ACKNOWLEDGMENT}

I am much indebted to Mrs. M. M. Soekarjo for her revision of the English text.

\section{REFERENCES}

Arnoldo, M. 1954. Wat in het wild groeit en bloeit op Curaçao, Aruba en Bonaire. Zakflora. Curaçao. (2nd ed. 1964).

Bartram, E. B. 1949. Mosses of Guatemala. Fieldiana: Botany 25.

Boldingr, I. 1909. The Flora of St. Eustatius, Saba and St. Martin. The Flora of the Dutch West Indian Islands I. Leiden.

1913. Flora voor de Nederlandsch West-Indische Eilanden, Amsterdam. 
Boldingh, I. 1914. The Flora of Curaçao, Aruba and Bonaire. The Flora of the Dutch West Indian Islands II. Leiden.

Florschutz, P. A. 1964. in J. Lanjouw, Flora of Suriname, Vol. VI, part I. Musci. Leiden.

Stofrers, A. L. 1956. The vegetation of the Netherlands Antilles. Utrecht. 1962. (editor) Flora of the Netherlands Antilles. Utrecht. 